\title{
$\mathrm{Al}-\mathrm{Cu}-\mathrm{Mg}$ 系合金の時効挙動に及ぼす銅， マグネシウム添加量と焼入れ速度の影響
}

\author{
鈴木 太一* · 八太 秀周*·吉田 英雄**
}

Journal of The Japan Institute of Light Metals, Vol. 68, No. 7 (2018), 333-338

(C) 2018 The Japan Institute of Light Metals

\section{Effect of copper and magnesium contents and quenching rate on artificial age hardening behavior of $\mathrm{Al}-\mathrm{Cu}-\mathrm{Mg}$ alloys}

\begin{abstract}
Taichi SUZUKI*, Hidenori HATTA* and Hideo YOSHIDA**
The effect of the copper and magnesium contents and quenching rate during quenching on the artificial age hardening behavior of $\mathrm{Al}-\mathrm{Cu}-\mathrm{Mg}$ alloys was investigated. For the higher copper-containing specimens as conventional 2000 series aluminum alloys, like AA2024, precipitation of the stable phases increased as the quenching rate decreased under the as-quenched conditions. The maximum hardness after the artificial aging of air cooled (AC) specimens was much lower than that of the water quenched (WQ) specimens. On the other hand, for the lower copper-containing specimens, coarse precipitation did not increase even in the case of the AC specimens. The age hardening behaviors of the WQ and AC specimens were very similar such that the maximum hardness and aging rate were almost the same. Many parts of the fine precipitates that increased the hardness were thought to be the GPB zone or fine $\mathrm{S}^{\prime}$ phase for the WQ specimens and relatively coarse $\mathrm{S}^{\prime}$ phase for the AC specimens. From the calculated CCT diagrams, the lower copper-containing specimens could maintain the copper and magnesium in the solid solution state during air cooling, so they could be quenched at a rather slower quenching rate like air cooling.
\end{abstract}

(Received January 15, 2018 Accepted May 8, 2018)

Keywords: $\mathrm{Al}-\mathrm{Cu}-\mathrm{Mg}$ alloy; quenching rate; artificial age hardening; precipitation; CCT diagram

\section{1. 緒言}

主要添加元素として銅やマグネシウムを含有する2000系 アルミニウム合金 (Al- $\mathrm{Cu}-\mathrm{Mg}$ 系合金) は代表的な熱処理型 合金の一つである。この合金系は時効析出により高い強度が 得られることから輸送機材料や構造部品等に広く用いられて いる。ただし熱処理型合金のうち特に2000系や銅添加量の多 い7000系合金は一般に焼入れ感受性が高く, 焼入れ時の冷 却が不十分であると溶体化処理後の冷却時に固溶した溶質元 素の粗大析出が進行し，母相中の固溶量が減少して時効硬化 能が低下する。このため時効処理後に充分な強度を得るには 焼入れ時の析出を抑制することが必要であり，多くの熱処理 型合金では，実用的には溶体化処理直後に水冷で焼入れする 等の手法がとられている。しかしこのような焼入れは工業的 に大規模な処理設備が必要となるため，熱処理型合金の焼入 れ感受性を低く抑えることができれば，すなわち水冷での焼 入れを不要とできれば，より簡便な工程での生産が可能にな ると期待される。2000系合金においては，これまで主要添加 元素に加えマンガン, クロム, ジルコニウムなどの微量元素 量を調整することで焼入れ感受性を低くする検討はいくつか
例があるものの，主要添加元素である銅やマグネシウム添加 量, 特にA2024アルミニウム合金等の一般的な2000系合金に 比べ銅, マグネシウム添加量が少ない場合の焼入れ感受性に 関する検討はあまり見られない。また時効特性に関する研究 の多くは焼入れ時に水冷等冷却速度の大きな手法を用いてお り, 水冷よりも冷却速度が小さい場合に注目した報告例は少 ない1) -3)。そこで今回銅, マグネシウム添加量を変化させ, さらに焼入れ時の冷却を水冷, 放冷, 炉冷の条件にて実施し, $\mathrm{Al}-\mathrm{Cu}-\mathrm{Mg}$ 系合金の焼入れ感受性に及ぼす銅，マグネシウム 添加量と焼入れ速度の影響について調査を行った。

\section{2. 実験方法}

供試材として, 銅, マグネシウム添加量を銅：1.0〜 $4.0 \mathrm{mass} \%$ (以下 $\%$ と表記) の範囲，またマグネシウムは $0.5 \%$ および $1.5 \%$ とした 6 種類の合金を作製した。供試材成分を Table 1 に示す。なお供試材のうち $4.0 \mathrm{Cu}-1.5 \mathrm{Mg}$ は A2024に 相当する成分である。これらの合金成分を有する直径 $90 \mathrm{~mm}$ のビレットを半連続鋳造法により鋳造し, $470^{\circ} \mathrm{C} て ゙ ~ 8 \mathrm{~h}$ の均 質化処理を施した後, 誘導加熱炉にて $500^{\circ} \mathrm{C} に$ 約 $5 \mathrm{~min}$ で昇 温し，幅 $35 \mathrm{~mm}$, 厚さ $3 \mathrm{~mm}$ の形状へ熱間押出加工を行った。

*株式会社UACJ R\&Dセンター（†455-8670 愛知県名古屋市港区千年3-1-12） Research \& Development Division, UACJ Corporation (3-112 Chitose, Minato-ku, Nagoya-shi, Aichi 455-8670) E-mail: suzuki-taichi@uacj.co.jp

**超々ジュラルミン研究所〔元 株式会社UACJ 技術開発研究所（名古屋市） ESD LAB〔former Research and Development Division, UACJ Corporation (Nagoya-shi, Aichi)] E-mail: yoshida-esdlab@hotmail.com 
Table 1 Chemical composition of specimens (mass\%).

\begin{tabular}{c|c|c|c|c|c|c|c|c|c}
\hline \hline Alloy & $\mathrm{Si}$ & $\mathrm{Fe}$ & $\mathrm{Cu}$ & $\mathrm{Mn}$ & $\mathrm{Mg}$ & $\mathrm{Cr}$ & $\mathrm{Zn}$ & $\mathrm{Ti}$ & $\mathrm{Al}$ \\
\hline $1.0 \mathrm{Cu}-0.5 \mathrm{Mg}$ & 0.07 & 0.15 & 0.96 & 0.62 & 0.47 & $<0.01$ & $<0.01$ & $<0.01$ & $\mathrm{Bal}$. \\
$1.0 \mathrm{Cu}-1.5 \mathrm{Mg}$ & 0.07 & 0.14 & 0.98 & 0.62 & 1.43 & $<0.01$ & $<0.01$ & $<0.01$ & $\mathrm{Bal}$ \\
$2.0 \mathrm{Cu}-0.5 \mathrm{Mg}$ & 0.07 & 0.15 & 1.94 & 0.62 & 0.48 & $<0.01$ & $<0.01$ & $<0.01$ & $\mathrm{Bal}$. \\
$2.0 \mathrm{Cu}-1.5 \mathrm{Mg}$ & 0.07 & 0.15 & 1.99 & 0.61 & 1.47 & $<0.01$ & $<0.01$ & $<0.01$ & $\mathrm{Bal}$. \\
$4.0 \mathrm{Cu}-0.5 \mathrm{Mg}$ & 0.07 & 0.14 & 3.85 & 0.61 & 0.47 & $<0.01$ & $<0.01$ & $<0.01$ & $\mathrm{Bal}$. \\
$4.0 \mathrm{Cu}-1.5 \mathrm{Mg}$ & 0.07 & 0.14 & 3.95 & 0.61 & 1.46 & $<0.01$ & $<0.01$ & $<0.01$ & $\mathrm{Bal}$. \\
\hline
\end{tabular}

Table 2 Quenching rate of each quenching method.

\begin{tabular}{l|c}
\hline \hline \multicolumn{1}{c|}{ Quenching method } & Quenching rate $\left({ }^{\circ} \mathrm{C} / \mathrm{s}\right)$ \\
\hline Water quenching (WQ) & approx. 30 \\
Air cooling (AC) & 1 \\
Furnace cooling (FC) & 0.008 \\
\hline
\end{tabular}

この時, 押出速度は $5 \mathrm{~m} / \mathrm{min}$ とした。

上記で作製した押出材に対し，大気炉にて $500^{\circ} \mathrm{C} て ゙ 1 \mathrm{~h} の$ 溶体化処理を施し, その後水冷, 空冷, 炉冷にて室温まで冷 却した。各条件の冷却速度を Table 2 に示す。冷却後はたた

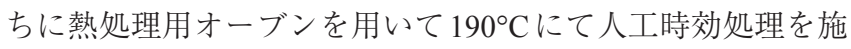
した。

冷却中の析出状態を調査するため, 溶体化処理後冷却まま の供試材断面組織を走査型電子顕微鏡（SEM）にて観察し た。また時効挙動を調査するため, 供試材は人工時効処理中 に所定の時間にて取り出し, その時点での硬さおよび導電率 を測定した。人工時効処理後の供試材は析出相の同定を行う ため, 透過型電子顕微鏡（TEM）観察および示差熱（DSC） 分析を実施した。

\section{3. 実 験 結 果}

\section{1 断面 SEM 観察結果}

SEMによる断面組織観察結果を Fig. 1 に示す。図中には溶 体化処理後冷却ままの導電率も併せて示した。 $1.0 \mathrm{Cu}-0.5 \mathrm{Mg}$ や $1.0 \mathrm{Cu}-1.5 \mathrm{Mg}, 2.0 \mathrm{Cu}-0.5 \mathrm{Mg}, 2.0 \mathrm{Cu}-1.5 \mathrm{Mg}$ では冷却速度によ る析出状況の差は小さく, 冷却速度が小さい炉冷の場合でも 粗大な析出物はわずかしか観察されなかった。また導電率 の変化も小さく，特に水冷と空冷を比較するとその差は数\% 程度であった。一方で $4.0 \mathrm{Cu}-0.5 \mathrm{Mg}$ や $4.0 \mathrm{Cu}-1.5 \mathrm{Mg}$ では水冷, 空冷，炉冷と冷却速度が遅くなるにつれて粒界析出物や粗大 な安定相が多く観察された。また導電率の変化も大きく, 特 に炉冷では水冷に比べ導電率の值で $10 \%$ IACS（International Annealed Copper Standard）以上の值の差を示した。

\section{2 硬さ測定結果}

人工時効処理中の硬さ測定結果を Fig. 2 に示す。まず冷却 ままの硬さの值は, いずれも空冷 > 水冷 > 炉冷の順に大きく なる傾向が見られた。時効処理時間の増加とともに硬さの 值も大きくなるが, $1.0 \mathrm{Cu}-0.5 \mathrm{Mg}, 1.0 \mathrm{Cu}-1.5 \mathrm{Mg}, 2.0 \mathrm{Cu}-0.5 \mathrm{Mg}$, $2.0 \mathrm{Cu}-1.5 \mathrm{Mg}$ では水冷と空冷でほほ同様に2段階の時効硬化 挙動を示した。またピーク時効時の硬さについては水冷と空 冷で同等か空冷の方がやや大きい值であり, 焼入れ後の冷 却速度による差は小さい結果となった。なおピーク時効まで の時間は $1.0 \mathrm{Cu}-0.5 \mathrm{Mg}, 1.0 \mathrm{Cu}-1.5 \mathrm{Mg}$ では $70 \sim 100 \mathrm{~h}$ 付近, ま
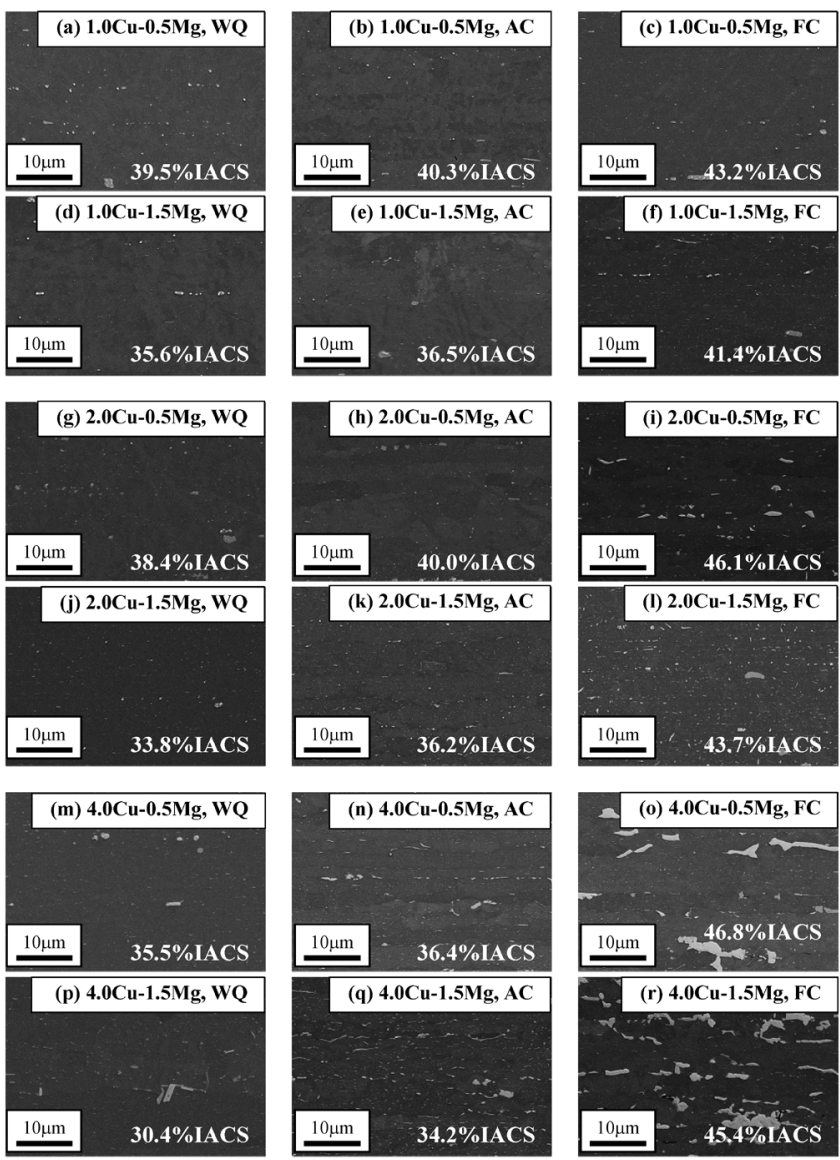

Fig. 1 SEM images of specimens under the as-quenched conditions. The electrical conductivity of the conditions is indicated in the lower right of each image.

た $2.0 \mathrm{Cu}-0.5 \mathrm{Mg}, 2.0 \mathrm{Cu}-1.5 \mathrm{Mg}$ では20〜 $50 \mathrm{~h}$ 付近であり，いず れも水冷材に比べ空冷材の方で時効速度が遅くなる傾向が 見られた。一方従来 2000 系合金程度の銅を含有する合金で は, $4.0 \mathrm{Cu}-0.5 \mathrm{Mg}$ で水冷と空冷でよく似た時効挙動を示すも のの, ピーク時効時の硬さは空冷の方が明確に小さい值と なった。また $4.0 \mathrm{Cu}-1.5 \mathrm{Mg}$ は水冷材では従来 $\mathrm{A} 2024$ と同様の 時効挙動を示していたが, 空冷材では時効の初期から硬さが あまり変化せず，ピーク時効時の值で硬さに 20 以上の差が 出る結果となり, 溶体化処理後に空冷で泠却したことによる 時効硬化能の大きな低下が認められた。なおピーク時効まで の時間はいずれも水冷材が $20 \mathrm{~h}$ 程度であったのに対し空冷材 は 5 10h 程度であり, その後は硬さが大きく低下している ことから, 空冷材では過時効側に移行するまでの時間が短く なる結果となった。炉冷材についてはいずれの合金でも冷却 ままから硬さがほとんど変化しておらず，時効処理による硬 

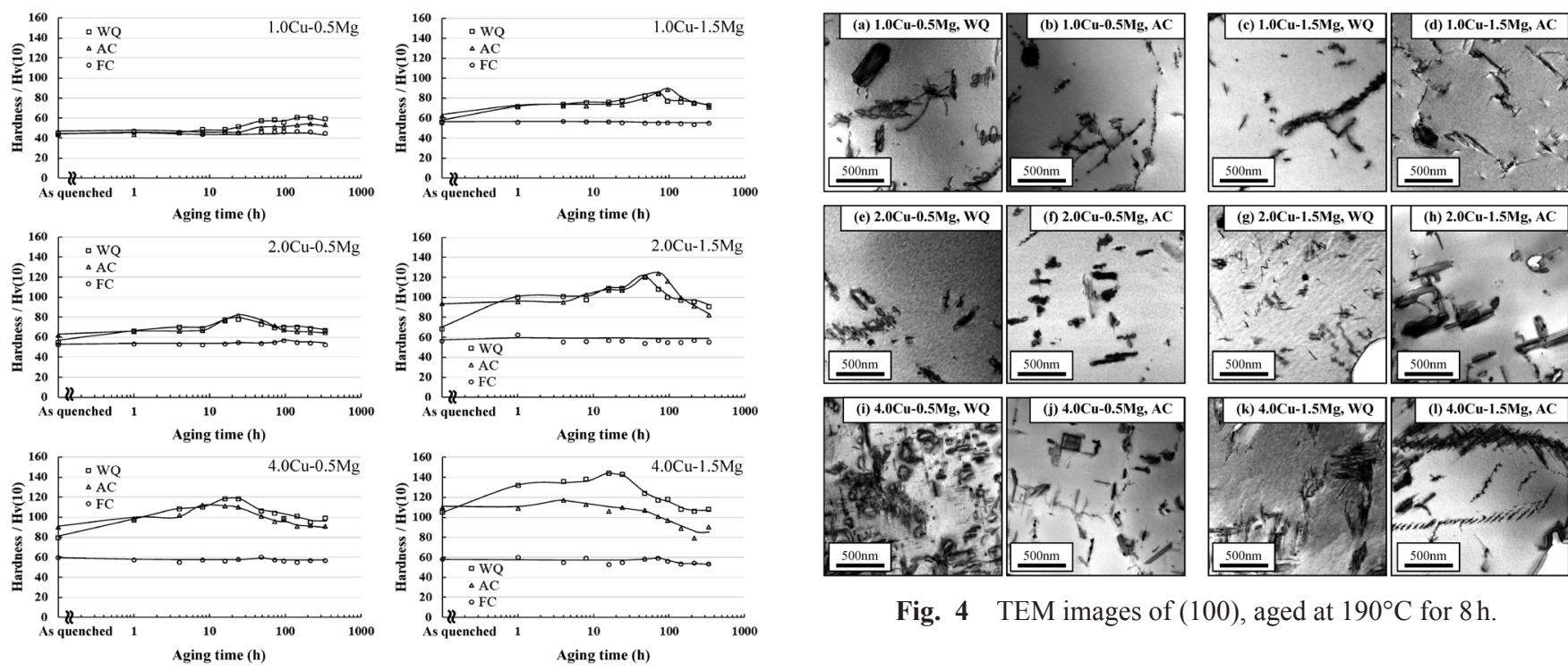

Fig. 4 TEM images of (100), aged at $190^{\circ} \mathrm{C}$ for $8 \mathrm{~h}$.

Fig. 2 Vickers hardness after artificial aging at $190^{\circ} \mathrm{C}$.
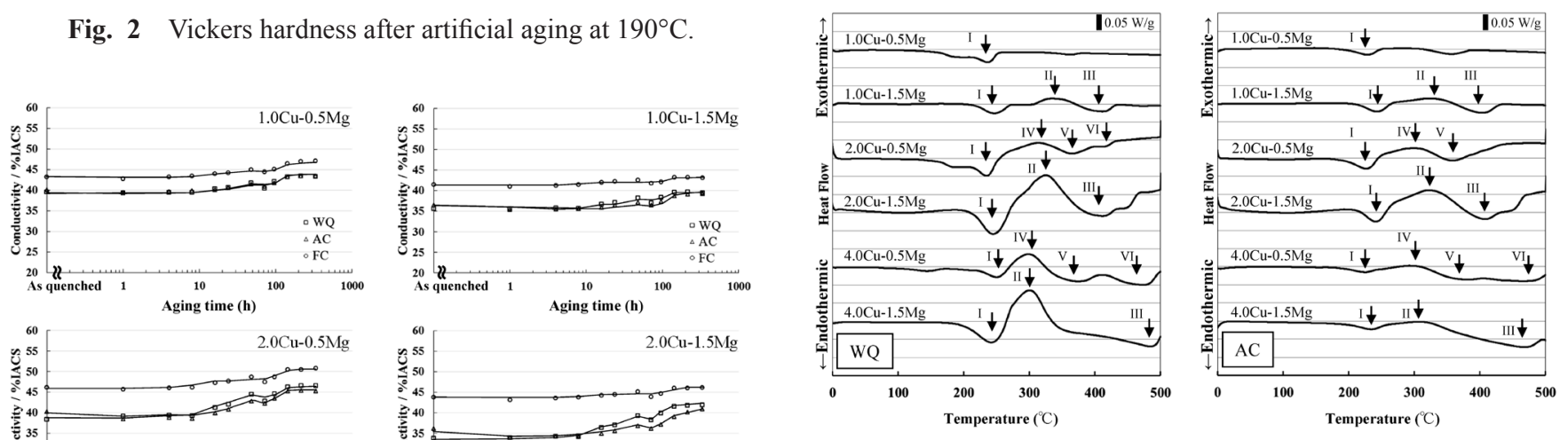

Fig. 5 DSC analysis, aged at $190^{\circ} \mathrm{C}$ for $8 \mathrm{~h}$. I: GP (GPB) dissolution, II: $\mathrm{S}^{\prime}$ (S) formation, III: $\mathrm{S}^{\prime}$ (S) dissolution, IV: $\theta^{\prime}(\theta)$ formation, V: $\theta^{\prime}$ dissolution, VI: $\theta$ dissolution.

\section{位ループや転位ループ上への $\mathrm{S}^{\prime}$ 相の析出が観察された ${ }^{4), 5)}$}

\subsection{DSC 分析結果}

DSC 分析の結果を Fig. 5 に示す。図中には推定される各析 出相の吸熱, 発熱ピークをI〜VIで示した。まずいずれの供 試材とも $220 \sim 250^{\circ} \mathrm{C}$ 付近で GPゾーンまたは GPBゾーンの 分解に伴う吸熱ピークが認められた ${ }^{6), 7)}$ 。水冷材と空冷材を 比較すると, 全体として水冷材の方で吸熱量が多くなる傾 向が見られたが， $1.0 \mathrm{Cu}-0.5 \mathrm{Mg}, 1.0 \mathrm{Cu}-1.5 \mathrm{Mg}, 2.0 \mathrm{Cu}-0.5 \mathrm{Mg}$ で は水冷材と空冷材で大きな差は認められなかった。 $2.0 \mathrm{Cu}-$ $1.5 \mathrm{Mg}$ 空冷材では水冷材の半分程度の吸熱量であった。一方 $4.0 \mathrm{Cu}-0.5 \mathrm{Mg}, 4.0 \mathrm{Cu}-1.5 \mathrm{Mg}$ では空冷材の吸熱量は水冷材の半 分未満と大きく低下する結果となった。これはTEM観察に て水冷材で GPBゾーンが多く観察された結果と一致するも のであった。また $\mathrm{S}^{\prime}, \mathrm{S}, \theta^{\prime}, \theta$ 各相の析出（それぞれピーク II またはIV）に関しては，300 $350^{\circ} \mathrm{C}$ 付近の温度域における ピーク高さに注目した場合 $4.0 \mathrm{Cu}-0.5 \mathrm{Mg}$ では後述するように $\theta^{\prime}$ 相もしくは $\theta$ 相の析出に伴う発熱ピーク ${ }^{8)}$ が, それ以外の 合金では $\mathrm{S}^{\prime}$ 相もしくは $\mathrm{S}$ 相の析出に伴う発熱ピークが認めら れるが，その発熱量は空冷材の方が小さい結果となり，特に 銅を $2 \%$ 以上含有する合金で顕著であった。

\section{4. 考察}

\section{1 各供試材の析出相}

前述の通り，DSC分析の結果より合金成分により異なる 

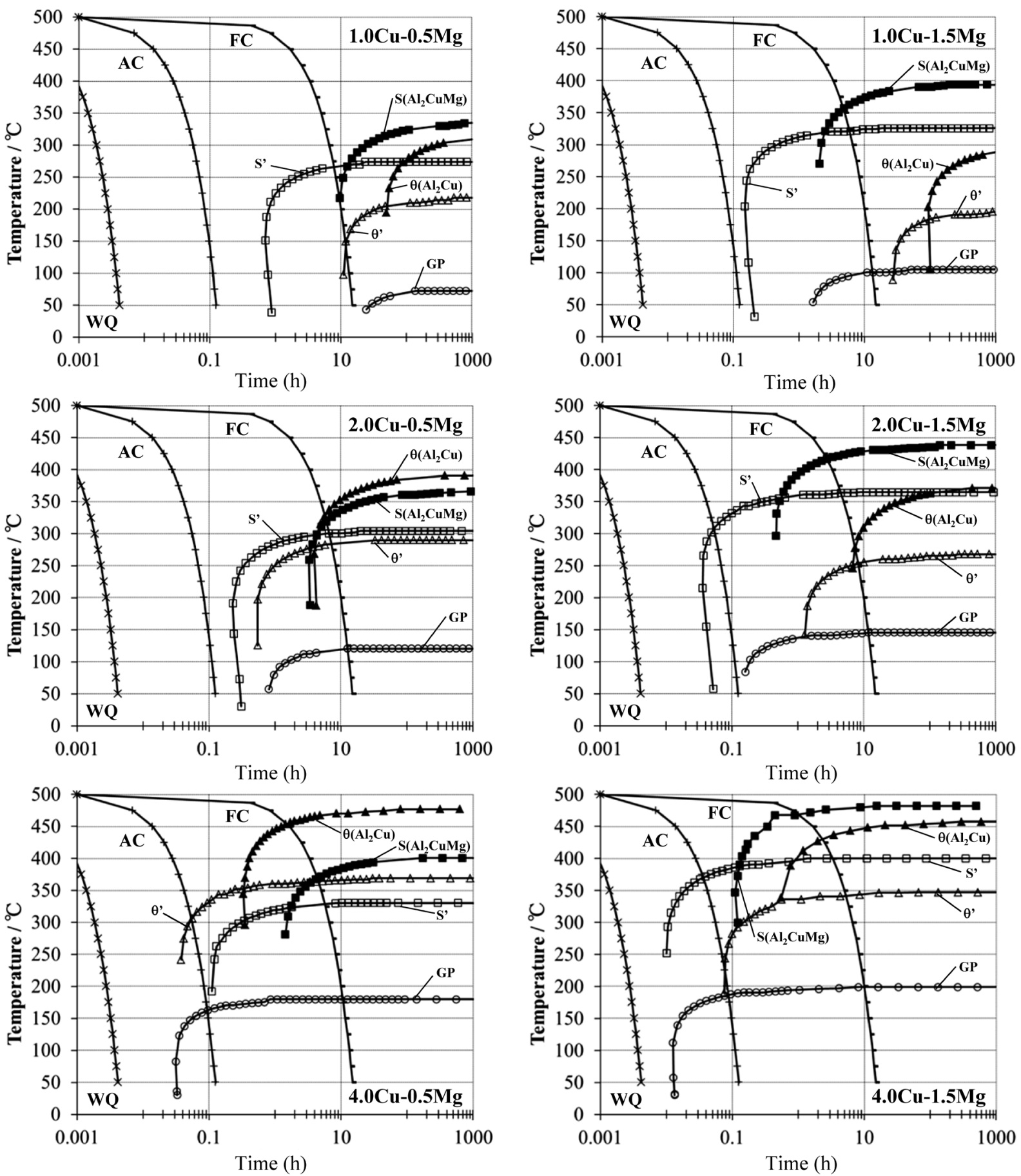

Fig. 6 CCT diagrams calculated by JMatPro.

発熱・吸熱ピークが認められた。ここで，各供試材成分にお ける析出相を整理する。

銅とマグネシウムを含有する2000系合金における時効析 出過程は
(1) $\alpha \rightarrow \mathrm{GP}(1) \rightarrow \mathrm{GP}$ (2) $\rightarrow \theta^{\prime} \rightarrow \theta$

(2) $\alpha \rightarrow \mathrm{GPB} \rightarrow \mathrm{S}^{\prime} \rightarrow \mathrm{S}$

の 2 つ反応に分類される。合金組成の比，すなわち含有す る銅とマグネシウムの重量比 $(\mathrm{Cu} / \mathrm{Mg})$ により時効析出過程 は異なり， $\mathrm{Cu} / \mathrm{Mg}>8$ では(1)の反応が, $4<\mathrm{Cu} / \mathrm{Mg}<8$ では(1) と (2)の反応の両方が, $1.5<\mathrm{Cu} / \mathrm{Mg}<4$ では(2)の反応が進行すると

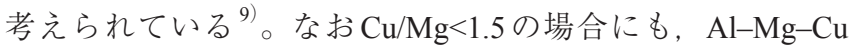
合金での検討結果 ${ }^{10)}$ から(2)の反応が進行すると考えられる。 上記より, 今回の供試材成分においては $4.0 \mathrm{Cu}-0.5 \mathrm{Mg}$ で(1)の
反応が, $2.0 \mathrm{Cu}-0.5 \mathrm{Mg}$ で(1)と(2)の反応が, その他の供試材で は(2)の反応が主に進行すると考えられた。

\section{2 溶体化処理後冷却中の析出}

SEM 観察の結果，銅添加量が $1.0 〜 2.0 \%$ と 2017 や 2024 などの従来 2000 系合金よりも少ないものでは冷却速度によ る粗大析出の差は小さかったが, 銅添加量がA2017や A2024 と同程度である $4.0 \mathrm{Cu}-0.5 \mathrm{Mg}$ や $4.0 \mathrm{Cu}-1.5 \mathrm{Mg}$ では, 水冷より も冷却速度が小さい場合に粗大な安定相の析出が進行して いた。溶体化処理後冷却中の析出について考察を行うため, JMatProを用いて各供試材のCCT 線図を作製した。その結果 をFig. 6 に示す。なお今回作製したCCT線図においてはGP ゾーンとGPBゾーンは計算ソフトの仕様上区別されていな い。 
CCT 線図より，まず銅，マグネシウム添加量ともに少な い $1.0 \mathrm{Cu}-0.5 \mathrm{Mg}, 2.0 \mathrm{Cu}-0.5 \mathrm{Mg}$ では炉冷の場合を除き冷却中に $\mathrm{S}$ 相や $\theta$ 相等の安定相の析出ノーズを通過しない。このため 冷却中の粗大析出量が少なかったと考えられた。ただし $\mathrm{S}^{\prime}$ 相 や $\theta^{\prime}$ 相等の準安定相については，冷却中に析出ノーズ付近を 通過するため，実際には時効硬化能を低下させない程度にこ れらの相の析出が進行していると考えられる。

一方これらに対しマグネシウム量を増加させた $1.0 \mathrm{Cu}-$ $1.5 \mathrm{Mg}$ や $2.0 \mathrm{Cu}-1.5 \mathrm{Mg}$ ，あるいは $4.0 \mathrm{Cu}-0.5 \mathrm{Mg}, 4.0 \mathrm{Cu}-1.5 \mathrm{Mg}$ では，同様に炬冷の場合を除き安定相の析出ノーズ自体は通 過しないものの， $\mathrm{S}^{\prime}$ 相や $\theta^{\prime}$ 相， GPB等準安定相の析出ノーズ やその付近を通過する。特にA2024に相当する $4.0 \mathrm{Cu}-1.5 \mathrm{Mg}$ では空冷の場合には安定相の析出ノーズ付近を通過する。こ のため，実際にはSEM観察の結果のように水冷，空冷，炉 冷と冷却速度が遅くなるにつれて安定相が粗大に析出したも のと考えられた。

\section{3 溶体化処理後の冷却速度が異なる場合の時効挙動}

これまでの結果を踏まえ，溶体化処理後の冷却速度が異な る場合の時効挙動について考察を行った。まず $4.0 \mathrm{Cu}-0.5 \mathrm{Mg}$ や $4.0 \mathrm{Cu}-1.5 \mathrm{Mg}$ のように銅が $\mathrm{A} 2024$ などと同程度含まれる場 合には，空冷程度の冷却速度では安定相である $\mathrm{S}$ 相や $\theta$ 相, また準安定相である $\mathrm{S}^{\prime}$ 相や $\theta^{\prime}$ 相の粗大な析出が進行すると考

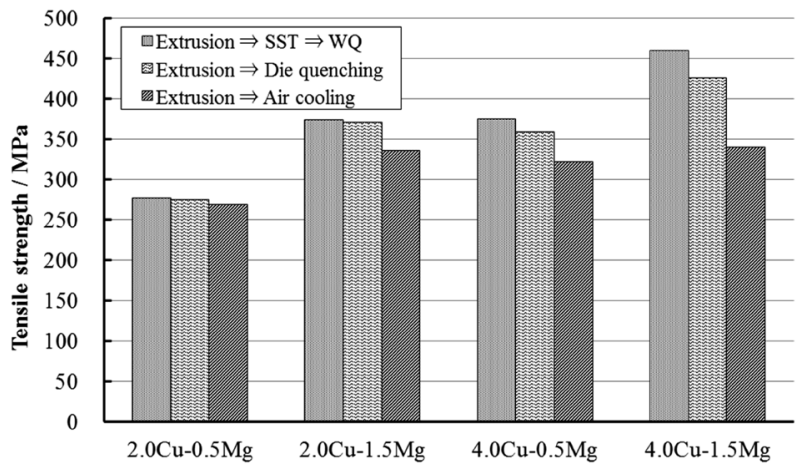

Fig. 7 Mechanical properties of specimens. Each specimen was quenched in (1) WQ after SST at $500^{\circ} \mathrm{C}$, (2) Die quenching just after extrusion, (3) Air cooling after extrusion, following artificial aging at $190^{\circ} \mathrm{C}$ for $24 \mathrm{~h}$.
えられる。なお冷却ままの硬さを比較してみると空冷の方が 大きい值を示すことから, 時効初期においては冷却中に析出 した準安定相は硬さの上昇にわずかに寄与していると考えら れる。ただしその後の時効挙動としては $4.0 \mathrm{Cu}-1.5 \mathrm{Mg}$ で顕著 なように安定相の粗大析出により母相中の溶質元素が消費さ れており，かつ上記準安定相の粗大化が進行するため，その 後時効処理を施した際の時効硬化能が水冷の場合と比べて大 きく低下する。

一方でその他供試材のようにA2024などよりも銅添加量が 少ない場合には, 空冷程度の冷却速度でも安定相の粗大析出 が進行しにくい。また $\mathrm{S}^{\prime} や \theta^{\prime}$ 等の準安定相析出ノーズ付近を 通過するため, これらの相の析出は進行するものの, 溶質元 素の量が比較的少ないため冷却中には粗大化しにくいと考 えられた。特に $2.0 \mathrm{Cu}-1.5 \mathrm{Mg}$ ではその後時効処理を施すこと で, TEM観察およびDSC 分析の結果より水冷ではGPBゾー ンの析出を生じ，また空冷では冷却中に $\mathrm{S}^{\prime}$ 相の析出を生じ て GPBゾーンの生成が抑制され時効初期の時効速度が遅く なっているため, 主として $\mathrm{S}^{\prime}$ 相の析出が進行し硬さが上昇し ていくと考えられる。しかしながら冷却中の粗大析出によ る溶質元素の消費が抑制され固溶量の低下が少ないことか ら, 空冷材でも水冷材とほぼ同様の時効挙動を示したもの と考えられる。なおピーク時効時の硬さは特に $1.0 \mathrm{Cu}-1.5 \mathrm{Mg}$, $2.0 \mathrm{Cu}-0.5 \mathrm{Mg}, 2.0 \mathrm{Cu}-1.5 \mathrm{Mg}$ で水冷材よりも放冷材の方がわず かに高い結果となった。これは前述の通り冷却中に析出した 準安定相が粗大化しておらず，強度向上に寄与する $\mathrm{S}^{\prime}$ 相の数 密度が放冷材の方が多かったためであると考えられる。

\section{4 焼入れ感受性の比較}

以上の結果より，銅添加量が $2 \%$ 程度とA2024などよりも 少ない場合には，溶体化処理後の冷却速度が空冷程度であっ ても冷却中の粗大析出を抑制でき，焼入れ感受性が低くなる と考えられた。このように焼入れ感受性が低い熱処理型合金 では，例えば押出材であれば押出直後に水冷するダイクエン チ押出だけでなく，空冷しただけであっても正式焼入れ材と 同等程度もしくは近い強度を確保できると考えられた。そこ で $2.0 \mathrm{Cu}-0.5 \mathrm{Mg}, 2.0 \mathrm{Cu}-1.5 \mathrm{Mg}, 4.0 \mathrm{Cu}-0.5 \mathrm{Mg}, 4.0 \mathrm{Cu}-1.5 \mathrm{Mg}$ につ いて(1)熱間押出後に空冷で室温まで冷却後 $500^{\circ} \mathrm{C}$ で溶体化処 理し水冷焼入れ（正式焼入れ），(2) $500^{\circ} \mathrm{C}$ で熱間押出後ダイ

Table 3 Mechanical properties of specimens after each quenching method following artificial aging at $190^{\circ} \mathrm{C}$ for $24 \mathrm{~h}$. TS: Tensile Strength, YS: Yield Strength, EL: Elongation.

\begin{tabular}{|c|c|c|c|c|c|}
\hline Alloy & Quenching method & $\mathrm{TS}(\mathrm{MPa})$ & YS (MPa) & EL (\%) & $\begin{array}{c}\text { TS decrease ratio } v s . \text { WQ } \\
(\%)\end{array}$ \\
\hline $\begin{array}{l}2.0 \mathrm{Cu}-0.5 \mathrm{Mg} \\
2.0 \mathrm{Cu}-1.5 \mathrm{Mg} \\
4.0 \mathrm{Cu}-0.5 \mathrm{Mg} \\
4.0 \mathrm{Cu}-1.5 \mathrm{Mg}\end{array}$ & $\begin{array}{c}\text { Extrusion } \Rightarrow \mathrm{SST} \Rightarrow \\
\text { Water quenching (WQ) }\end{array}$ & $\begin{array}{l}278 \\
375 \\
376 \\
461\end{array}$ & $\begin{array}{l}187 \\
271 \\
283 \\
379\end{array}$ & $\begin{array}{l}18 \\
17 \\
14 \\
12\end{array}$ & $\begin{array}{l}- \\
- \\
-\end{array}$ \\
\hline $\begin{array}{l}2.0 \mathrm{Cu}-0.5 \mathrm{Mg} \\
2.0 \mathrm{Cu}-1.5 \mathrm{Mg} \\
4.0 \mathrm{Cu}-0.5 \mathrm{Mg} \\
4.0 \mathrm{Cu}-1.5 \mathrm{Mg}\end{array}$ & Extrusion $\Rightarrow$ Die quenching & $\begin{array}{l}276 \\
372 \\
360 \\
427\end{array}$ & $\begin{array}{l}192 \\
273 \\
271 \\
347\end{array}$ & $\begin{array}{l}17 \\
16 \\
15 \\
12\end{array}$ & $\begin{array}{l}1 \\
1 \\
4 \\
7\end{array}$ \\
\hline $\begin{array}{l}2.0 \mathrm{Cu}-0.5 \mathrm{Mg} \\
2.0 \mathrm{Cu}-1.5 \mathrm{Mg} \\
4.0 \mathrm{Cu}-0.5 \mathrm{Mg} \\
4.0 \mathrm{Cu}-1.5 \mathrm{Mg}\end{array}$ & Extrusion $\Rightarrow$ Air cooling & $\begin{array}{l}270 \\
337 \\
323 \\
341\end{array}$ & $\begin{array}{l}192 \\
217 \\
225 \\
231\end{array}$ & $\begin{array}{l}17 \\
17 \\
15 \\
13\end{array}$ & $\begin{array}{r}3 \\
10 \\
14 \\
26\end{array}$ \\
\hline
\end{tabular}


クエンチで室温まで冷却，(3)熱間押出後空冷で室温まで冷 却，を行い $190^{\circ} \mathrm{C} て ゙ 24 \mathrm{~h}$ の工時効処理を施し，機械的性質 を比較した（Fig. 7, Table 3）。なお強度の差を比較するため 各冷却手法で得られた供試材の引張強さについて，正式焼入 れ材の強度を分母, 正式焼入れ材との強度の差を分子とし, 百分率に換算した強度低下率を求めた。

その結果, $4.0 \mathrm{Cu}-0.5 \mathrm{Mg}$ や $4.0 \mathrm{Cu}-1.5 \mathrm{Mg}$ のように $\mathrm{A} 2024$ 程 度の銅添加量では正式焼入れしたもの以外では強度が低下 し, 特に $4.0 \mathrm{Cu}-1.5 \mathrm{Mg}$ の押出後空冷まま材では正式焼入れ材 と比べ $30 \%$ 近い強度低下率を示した。一方で $2.0 \mathrm{Cu}-0.5 \mathrm{Mg}$ や $2.0 \mathrm{Cu}-1.5 \mathrm{Mg}$ では押出後ダイクエンチ材であれば正式焼入れ 材と同等程度の強度であり，また押出後空冷ままでも $10 \%$ 以下の強度低下率であり, 熱間押出後の冷却速度が空冷程度 であっても焼入れが可能であることが確認された。

\section{5. 結言}

$\mathrm{Al}-\mathrm{Cu}-\mathrm{Mg}$ 系合金において主要添加元素である銅，マグネ シウム添加量および溶体処理後の冷却速度を変化させ, これ らが焼入れ感受性に及ぼす影響を調査し，以下の結論を得 た。

（1）焼入れ後冷却ままの断面組織観察より，銅添加量が 1.0 ～ $2.0 \%$ と A2024などの従来 2000 系アルミニウム合金より も少ない場合には冷却速度による析出状況の差は小さく，冷 却速度の大小によらず粗大な析出物はわずかしか観察され なかった。一方でA2024などと同程度の銅を含む場合には水 冷，空冷，炉冷と冷却速度が遅くなるにつれて粗大な安定相 や粒界析出物が多く観察された。

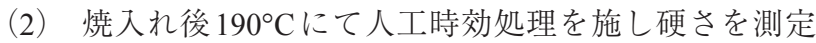
した結果，銅添加量が $2.0 \%$ 以下では水冷と空冷でほぼ同様 の時効挙動を示し，またピーク時効時の硬さについては水冷 と空冷で同等か空冷の方がやや大きい值であり，焼入れ後の
冷却速度による差は小さい結果となった。一方で銅添加量が $4.0 \%$ の場合にはピーク時効時の硬さは空冷の方が明確に小 さい值となり，溶体化処理後に空冷で冷却したことによる時 効硬化能の大きな低下が認められた。炉冷材についてはいず れの合金でも冷却ままから硬さがほとんど変化しておらず, 時効処理による硬さの上昇は認められなかった。

（3） TEM観察および DSC 分析の結果，いずれの供試材も 水冷材では点状または微細な棒状の GPB ゾーンが多く認め られたが, 空冷材ではそれらは減少し, 代わりにラス状の比 較的粗大な $\mathrm{S}^{\prime}$ 相の析出が観察された。

（4） CCT 線図より，銅添加量がA2024などと同程度含ま れる場合には，空冷程度の冷却速度では安定相である $\mathrm{S}$ 相や $\theta$ 相，また準安定相である $\mathrm{S}^{\prime}$ 相や $\theta^{\prime}$ 相の粗大な析出が進行し たため, 時効処理を施した際の時効硬化能が水冷の場合と比 べて大きく低下したと考えられた。一方で銅添加量が $2 \%$ 以 下と少ない場合には, 空冷程度の冷却速度でも安定相の粗大 析出が進行しにくいため時効硬化能が低下せず，焼入れが可 能であったと考えられた。

\section{参 考 文 献}

1）鈴木 壽, 伊藤吾朗：軽金属, 36 (1986)，157-161

2）菅野幹宏，鈴木 壽，系井一博：軽金属，36（1986）， 616-621.

3) 河野紀雄, 佐久間孝, 室町繁雄, 渡辺久藤：軽金属, 38 (1988), 172-176.

4) J. M. Silcock: J. Inst. Met., 89 (1960), 203-210.

5) J. M. Silcock, T. J. Heal and H. K. Hardy: J. Inst. Met., 82 (1953), 239-248.

6) N. Gao, L. Davin, S. Wang, A. Cerezo and M. J. Starink: Mater. Sci. Forum, 396-402 (2002), 923-928

7) M. J. Starink, N. Gao, L. Davin, J. Yan and A. Cerezo: Philos. Mag., 85 (2005), 1395-1417.

8) M. J. Starink and P. van Mourik: Mater. Sci. Eng. A, 156 (1992), 183-194.

9) 里 達雄, 北岡山治, 神尾彰彦: 軽金属, 38 (1988), 558-578.

10）里＼cjkstart達雄：軽金属, 56（2006），592-601。 